小筋及ひ大筋正舫に於けるテンポとリスム

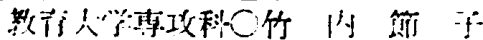

I. 研究目的

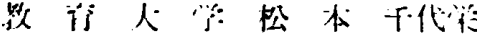

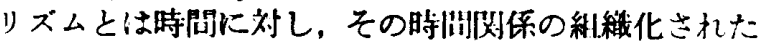
ものであるといら䚋点に立ち，動きのリズムをテンボの 面ふら考察し，それの持つ特性を把握してみた．知覚さ れしはズム感が小䇨に於いては直ぐ反応可能であろうと テ剆し大箭に於いてはどの様にそれが変化してくるかの 此較の基準とした，又同時に“力”の点から動きのりズ ムを考察してみた。

\section{II. 英积望及ひ方法}

1. Personal Tempo.

○小胳…」」」と紙上に印されたすのを見せこのパタ ーンを指頭で最す行い易いテンボで続ける様要求する。 一分間測定を䋓 10 回とる．何回打つたかを测定しそれ 在4倍して1分間のテンボとした。 各遂行間に 30 秒す 休想.

(0)大筋…小胼と同じパターンを床上 $30 \mathrm{~cm}$ の間隔を サイドステッブの様に移動しその際」」は右足で 2 问つ づ!片よで左足に体重を移しそれをくり返す．湘定回数は 小肪上同し。

2.あらゆるテンボの音刺使を与えた時の適応

動作は1と同じすので実際にメトロノームのテンボ $60,80,100,110,120,130,140,150,160,180$ 目/分を 刺激として与えそれに合わせて動作を遂行し，小筋は電 鍵打拍，大筋は電気接触による測定器を通じシグナルマ グネットを通して10秒一回転のキモグラフに竌録し一 動作は各テンポ毎 2 周記録した。

3. 力のリズム

スメドレー嘱力計にタンブールを操作した機械を使用 し30秒 1 回転の キモグラフに 5 周記録した。 パターン

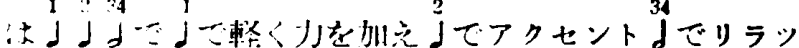

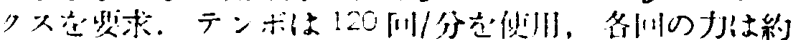

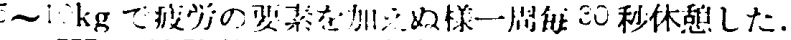

III. 破験者（いずれも女子）

大学舞踊部員 6 名〔舞踊 5 年以上释験者〕，大学ハレ 一ボール部員 5 名 (5 年以上)，同大学文学部学生 3 名 〔特にスボーツをやつていないもの〕.
IV.
Personal Tempo.

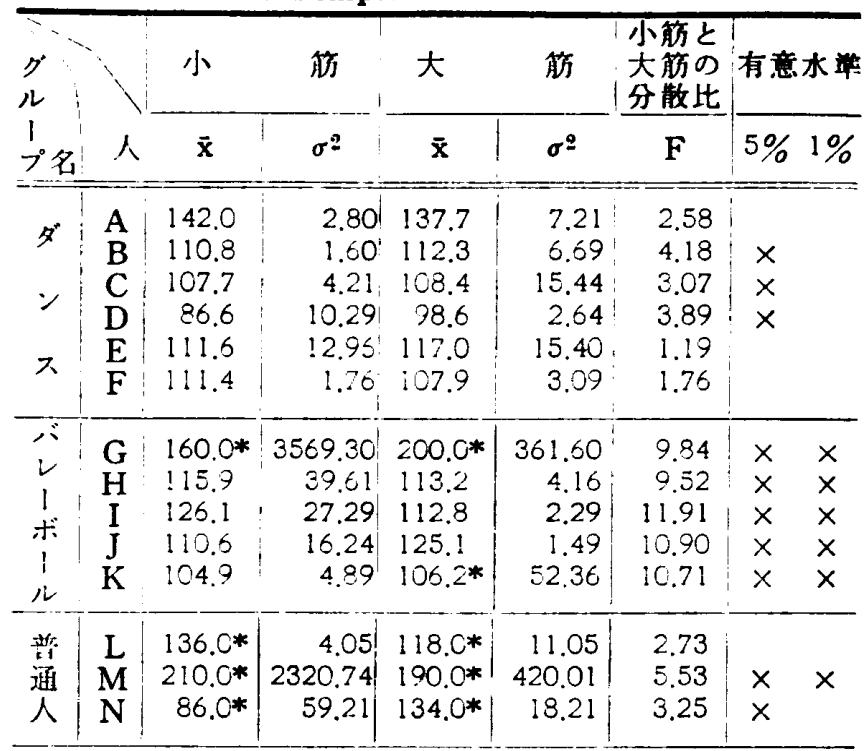

*は分散が大きいので中央傎をとつた。

10 段階の音刺制を与えたときの適応

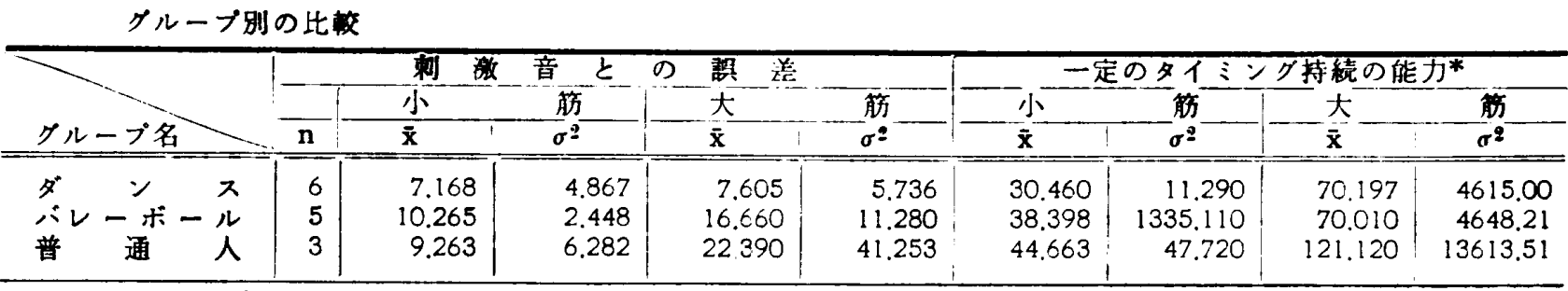

*各テンポに於ける $\mathrm{CV}=100 \sigma / \overline{\mathrm{x}}$ をとつた

各グループ間の差の検定

\begin{tabular}{|c|c|c|c|c|c|c|c|c|}
\hline & \multicolumn{4}{|c|}{ 制 湤 音 と $の$ 話 } & \multicolumn{4}{|c|}{ 二定のタイミング持繶の能力 } \\
\hline & $t($ 小箭 $)$ & 有意水海 & $\mathrm{t}$ (大肪) & 标意水㴤 & $\mathrm{t}($ 小筮 $)$ & 有管水淿 & $t(大+1 / 3)$ & 有意水潭 \\
\hline 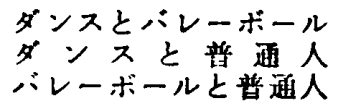 & $\begin{array}{l}2.4599 \\
0.9510 \\
0.6036\end{array}$ & $5 \%$ & $\begin{array}{l}4.9725 \\
3.2030 \\
1.1839\end{array}$ & $\begin{array}{l}0.5 \% \\
2.5 \%\end{array}$ & $\begin{array}{l}0.5168 \\
2.9220 \\
0.3940\end{array}$ & $2.5 \%$ & $\begin{array}{l}0.0410 \\
2.5174 \\
2.2778\end{array}$ & $\begin{array}{l}5 \% \\
5 \%\end{array}$ \\
\hline
\end{tabular}

グルーブ内の小筇と大第の能力の比夜

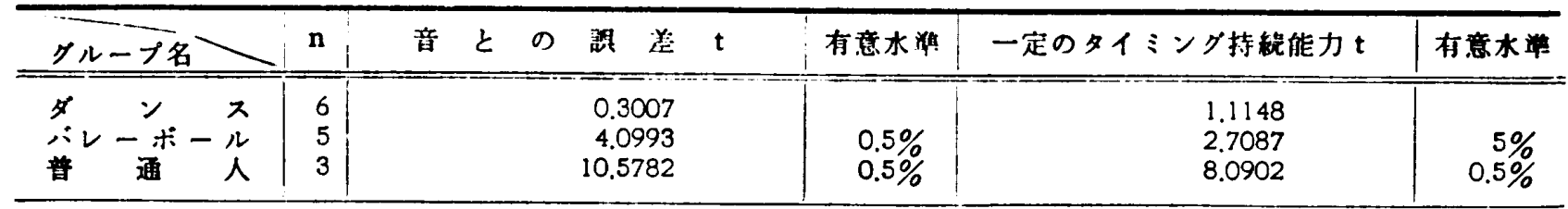

菬

以上のことから次のことが明らかとなつた。がンスを やる者はあらゆる速度の刺䍩音に対する反应が優れてお り一定の営えたリズムバターンを長く持涜できるのに比

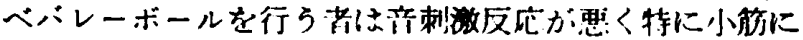
於いて要かつた。ひとつのハターンを㧧する能力い大

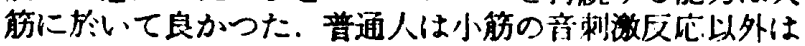
慧かつた。

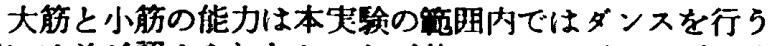
者には差が認められなかつたが他の二つのグループには 有意差が認められた。

ダンスに於けるリズムとして身体がきくといらことの

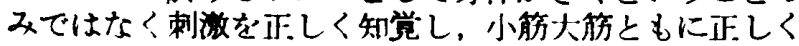
反応し，適代できる能力をいい，一定のハターンを小能

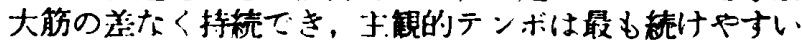

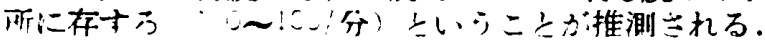

